\title{
GERIATRIC DENTISTRY - SURMOUNTING THE CHALLENGES
}

\author{
Dr. Ranjith Kumar $\mathbf{P}^{1}$ Dr Rohit Raghavan ${ }^{2}$ Dr. Nadeem Abdul Rahman*3 \\ Dr. Sumitra $\mathrm{S}^{4}$, Dr. Monisha $\mathrm{Vs}^{5}$ \\ Department of Prosthodontics, Royal Dental College, Palakkad, Kerala, India \\ Email id - 1 drranjithp@hotmail.com; ${ }^{2}$ drrovan@gmail.com; ${ }^{3}$ nadhee4u4ever@gmail.com
}

\section{$\underline{\text { Abstract }}$}

Geriatric dentistry is the branch of dentistry that emphasizes dental care for the elderly population and focuses upon patients with chronic physiological, physical and/or psychological changes or morbid conditions/ diseases. Gerodontics delivers dental care to older adults which involves diagnosis and treatment planning and prevention of problems associated with normal ageing and age-related diseases as an inter disciplinary manner with other medical professionals. Elderly patients are usually associated with oral manifestations due to various systemic conditions. It is important to alter the treatment mode with taking into account the psychological considerations of such patients. More stress must be given for prevention and early intervention to control the risk of oral diseases. It is important to educate dental professionals regarding the importance of geriatric services without any delay. This article makes an attempt to give the objectives, dietary guidelines and treatment considerations to meet the need of the geriatric patients.

Key words: Dentition, Geriatrics, Geriatric dentistry, General health, Nutrition, Oral health.

\section{Introduction}

Mouth is considered to be the mirror of overall health. Geriatric oral health status gives a total impression of their general health and diseases. As the lifespan has increased dramatically, the thought of retaining most of their teeth presents a healthy challenge to the oral health professionals for retaining the dentition ${ }^{1}$. It is a well-accepted fact that the geriatric management requires an extensive and more complicated approach for maintaining the dentition. Geriatric management should give important considerations for age-related physiological changes, systemic diseases and chronic medications for same with physical and social concerns ${ }^{2}$. It is important to maintain the oral health status as it not only improves quality of life but also enhances the general health of the elders ${ }^{3}$. Proper diagnosis and treatment planning is required as dental professionals deals with complex dental conditions with multiple medical conditions and must consider the psychological and economic stauts of the patients ${ }^{4,5}$. The treatment mode mainly involves oral health education with necessary clinical programmes for early intervention and prevention.

A decline in food intake is common among older people. A person's ability to chew food relies on the presence of effective teeth or dentures together with normal saliva flow. Food selection and masticatory performance potential provided by the quality of dentition would in some way be related to the nutritional status of individuals. Incorrect food selection and the consequent unbalanced intake of nutrients, as a result of the difficulty or incapability of consuming them, are associated with certain nutritional deficiencies ${ }^{9}$. 


\section{Objectives of gerodontics ${ }^{8,10}$}

1. To enable professionals to recognise and relieve the difficulties of the aged

2. To adopt a humanitarian attitude and maintain a better relationship for understanding the feelings and attitudes of the aged

3. To understand their special dental problems and plan proper treatment mode
4. Restoration or preservation of function in order to help the patient maintain not only an independent lifestyle but also their preferred lifestyle within those limits

5. To establish a balanced diet by taking into consideration the psychosocial and economic status

6. To provide temporary dietary supportive treatment, directed towards specific goals such as carries control, post-operative healing, or soft tissue conditioning.

\section{Geriatric oral changes $^{11,14}$}

\begin{tabular}{|c|c|}
\hline $\begin{array}{l}\text { Alteration in } \\
\text { olfaction }\end{array}$ & Number of taste buds appears to decrease with age. \\
\hline Salivary function & $\begin{array}{l}\text { Xerostomia is a condition of dry mouth as a result of diminished } \\
\text { salivary flow commonly found in the elderly. It is not effected } \\
\text { directly by aging but depends upon factors which responsible for } \\
\text { secretion of saliva. }\end{array}$ \\
\hline $\begin{array}{l}\text { Oral mucosal } \\
\text { changes }\end{array}$ & $\begin{array}{l}\text { Pain, dryness \& burning sensation of the mouth, cracks in the lips. } \\
\text { Difficulty in swallowing and chewing of food. Taste is altered. }\end{array}$ \\
\hline $\begin{array}{l}\text { Muscle function and } \\
\text { oral movements }\end{array}$ & $\begin{array}{l}\text { Ability of muscle function and tonicity decreases with age. Nerve } \\
\text { impulse gets impaired, which affect the activity of striated muscle } \\
\text { fibers. } \\
\text { Due to this it prolongs the chewing time and strokes. }\end{array}$ \\
\hline $\begin{array}{l}\text { Temporomandibular } \\
\text { joint pain }\end{array}$ & $\begin{array}{l}\text { With age, the glenoid fossa can become shallower and the head of } \\
\text { the condyle flatter. Perforation or damage of articular disc } \\
\text { between the condyle and fossa by this change in } \\
\text { temporomandibular relationships and limits the range of } \\
\text { movements of the jaws. }\end{array}$ \\
\hline Edentulism & $\begin{array}{l}\text { Lack of dentition does not necessarily mean dietary intake will be } \\
\text { compromised but considering that teeth serve as the primary } \\
\text { means of mastication as well as has an impact on socialization and } \\
\text { communication. }\end{array}$ \\
\hline Alveolar bone loss & $\begin{array}{l}\text { Alveolar bone density, like skeletal mass declines.The rate at which } \\
\text { this occurs is affected by oral hygiene, (intestinal absorption of } \\
\text { calcium) nutrition, genes, and hormones, maturity of bone density. }\end{array}$ \\
\hline
\end{tabular}

\section{Geriatric nutrition}

A balanced diet with adequate nutrients is essential for oral health and in turn, oral health enhances nutritional well being ${ }^{12}$. A proper nutritional assessment and suitable dietary advice is often a more appropriate way to cope with malnutrition than merely instituting prosthetic therapy. A person's ability to chew food relies on the presence of effective teeth 
or dentures together with normal saliva flow. Food selection and masticatory performance potential provided by the quality of dentition would in some way be related to the nutritional status of individuals. Incorrect food selection and the consequent unbalanced intake of nutrients, as a result of the difficulty or incapability of consuming them, are associated with certain nutritional deficiencies ${ }^{13}$.

William T Fischer (1955) conducted a study on prosthetics and nutrition. He explained that nutrition is one of the major factors that

\begin{tabular}{|c|c|c|}
\hline VITAMIN & SOURCES & DEFICIENCY \\
\hline Vitamin C & $\begin{array}{l}\text { Citrus food, Amla, guava, } \\
\text { tomatoes, green vegetables } \\
\text {,potatoes etc. }\end{array}$ & $\begin{array}{l}\text { Spongy, bleeding in the gums, painful } \\
\text { joints, delayed wound healing } \\
\text {,osteoporosis, hemorrhage, petechiae } \\
\text { and decrease immunity }\end{array}$ \\
\hline Vitamin B6 & $\begin{array}{l}\text { Meat, milk, fish, egg yolk, corn, } \\
\text { wheat }\end{array}$ & $\begin{array}{l}\text { Immune function, } \\
\text { Depression, irratibility,nervousness,ment } \\
\text { al confusion, Decrease in hemoglobin } \\
\text { levels }\end{array}$ \\
\hline $\begin{array}{l}\text { Vitamin } \\
\text { B12 }\end{array}$ & $\begin{array}{l}\text { Liver, kidney, } \\
\text { eggs,fish,pork,chicken,milk,curd }\end{array}$ & $\begin{array}{l}\text { Megaloblastic anemia,Impaired cognitive } \\
\text { function,Dementia,Neuropsychiatric } \\
\text { disorders,Lethargy and malaise, Glossitis, } \\
\text { Skin hyper pigmentation }\end{array}$ \\
\hline $\begin{array}{l}\text { Folic Acid / } \\
\text { Folacin }\end{array}$ & $\begin{array}{l}\text { Green, leafy vegetables, Whole } \\
\text { grains, eggs, cereals, liver, } \\
\text { kidney }\end{array}$ & $\begin{array}{l}\text { Glossitis, Skin hyper pigmentation, } \\
\text { Megaloblastic anaemia }\end{array}$ \\
\hline Vitamin D & $\begin{array}{l}\text { Fatty fish, fish liver oils, egg yolk, } \\
\text { milk }\end{array}$ & $\begin{array}{l}\text { Required for maintenance of bone health } \\
\text { and absorption of calcium } \\
\text { Bow legs,Beading of ribs }\end{array}$ \\
\hline Vitamin A & $\begin{array}{l}\text { Liver,kidney,eggyolk, milk, } \\
\text { cheese, butter, fish liver oils }\end{array}$ & $\begin{array}{l}\text { Bitot's spots (eyes), } \\
\text { Conjunctival and corneal xerosis } \\
\text { (dryness) } \\
\text { Xerosis of skin, Follicular hyperkeratosis }\end{array}$ \\
\hline Protein & $\begin{array}{l}\text { Fish, Chicken, Cheese, } \\
\text { Tofu,Beans,eggs,Yoghurts, }\end{array}$ & $\begin{array}{l}\text { Edema, Dull, dry, sparse, easily plucked } \\
\text { hair, Enlargement of parotid gland and }\end{array}$ \\
\hline
\end{tabular}

determines the success or failure of the prosthetic appliance in the mouths of aging people. Wical K.E and Brusse (1979) demonstrated the effects of calcium and vitamin D supplementation on alveolar ridge resorption in immediate denture patients. Massler M (1979) in his study on geriatric nutrition and osteoporosis concluded that the success or failure of an oral prosthesis depends as often on upon the health of the oral tissues as upon the technical skills of the prosthodontist. He also described the role of taste and smell in appetite in nutrition.

\begin{tabular}{|c|c|c|}
\hline & soymilk,Nuts,seeds & wasting of muscle. \\
\hline Iron & $\begin{array}{l}\text { Leafyvegetables,pulses,cereals, } \\
\text { fish.apples, dried fruits, } \\
\text { molasses }\end{array}$ & $\begin{array}{l}\text { Pallor, atrophic tongue Spoon nails, Pale } \\
\text { conjunctiva }\end{array}$ \\
\hline Niacin & $\begin{array}{l}\text { Beans,peanuts,Grains,liver,yeast } \\
\text {,milk,fish,eggs and vegetables }\end{array}$ & $\begin{array}{l}\text { Nasolabial seborrhea, Fissuring of eyelid } \\
\text { corners, Angular fissures around mouth, } \\
\text {,Pellagrous dermatitis,Mental confusion }\end{array}$ \\
\hline $\begin{array}{l}\text { Riboflavin/ } \\
\text { Vitamin B } 2\end{array}$ & $\begin{array}{l}\text { Mik and milk products, cereal } \\
\text { fruits, vegetables and fish }\end{array}$ & $\begin{array}{l}\text { Nasolabial seborrhea,Fissuring and } \\
\text { redness of eyelid corners and mouth, } \\
\text { Magenta colored tongue, Genital } \\
\text { dermatosis }\end{array}$ \\
\hline $\begin{array}{l}\text { Thiamine/ } \\
\text { Vitamin } \text { B }_{1}\end{array}$ & $\begin{array}{l}\text { Cereals, pulse, oil seeds, nuts } \\
\text {,yeast,pork,liver, heart,kidney, } \\
\text { milk }\end{array}$ & $\begin{array}{l}\text { Mental confusion, Irritability, pain in calf } \\
\text { muscle, loss of sensory and enlargement } \\
\text { of cardiac muscle }\end{array}$ \\
\hline Water & & $\begin{array}{l}\text { Rapid dehydration and associated } \\
\text { problems such as hypotension, elevated } \\
\text { body temperature and dryness of the } \\
\text { mucosa, decreased urine output and } \\
\text { mental confusion. }\end{array}$ \\
\hline Fibre & Bran, ,Bread, Cereal & $\begin{array}{l}\text { Gastrointestinal disturbances, increased } \\
\text { risk of myocardial infarction }\end{array}$ \\
\hline Zinc & $\begin{array}{l}\text { Animal products, whole } \\
\text { grains and dried beans }\end{array}$ & $\begin{array}{l}\text { Decreased taste acuity, } \\
\text { slow wound healing, mental confusion }\end{array}$ \\
\hline
\end{tabular}

Figure 2 - geriatric nutrition

Dietary considerations in denture wearers ${ }^{10}$ 


\section{First Day Juices is recommended in Vegetable fruit group \\ Bread cereal group in form of gruels cooked in either milk or water \\ Milk products \\ Egg , Meat soup}

\section{Second Day Vegetable fruit group - in addition to fruit and vegetable juices, tender cooked \& fruits and vegetables (skin and seeds must be removed) cooked carrots, \\ Third Day tender green beans. \\ Bread-cereal group: cooked cereals such as cream of wheat and softened \\ bread; boiled rice. \\ Milk products \\ Meat group: Fish, soft cooked chicken}

\section{Fourth Day Raw vegetables and sandwiches are the foods least preferred by denture wearers but in fact it require more force during mastication.}

Figure 3 - diet in denture wearers

\section{Treatment strategies}

With the rapid progress in dentistry over recent years, geriatric dentistry has been able to help people who have dental problems that are agerelated. As people get older, their dental needs become progressive, they show rapid signs of deterioration and wear, especially when it comes to their teeth, oral mucosa, jaws and other parts associated with oral health ${ }^{15}$.

We can broadly divide the treatment modalities into

\section{Preventive measures}

\section{Restorative measures}

\section{Preventive measures}

Active preventive measures by subjects cover oral health-maintaining behaviour. Recommended oral self-care consists of tooth-brushing twice daily, use of fluoride toothpaste, daily interdental cleaning, and avoidance of sugar. Regardless of dentate status, it is recommended that the elderly make dental visits at least every 6 months for clinical re-evaluation, depending upon their ability to perform oral hygiene.

\section{Active professional prevention}

To support and maintain a patient highly motivated, professional guidance should be on a regular basis, individualised, needs-related, and 
provide feedback on the patient's improvement during regular dental visits.

\section{Passive professional prevention}

Scaling and cleaning aim at removing supra- and subgingival plaque and calculus are important for the professional prevention of both dental caries and periodontal disease.

\section{Restorative measures}

Geriatric dentistry excels in restoring:

- Jaw structures;

- Gingival margins;

- Discoloured teeth;

- Missing teeth;

- Various types of other cosmetic and health related issues and

- It also helps people who may be taking excessive medications or may be slow to recover from or have sensitivity to dental surgery

\begin{tabular}{|c|c|}
\hline Excellent prognosis & Poor prognosis \\
\hline \multirow{2}{*}{$\begin{array}{l}\text { 1. Not demanding/exacting. } \\
\text { Quite accommodating }\end{array}$} & Demanding and exacting. \\
\hline & Pays attention to small details \\
\hline 2. Well-balanced lifestyle. & Preoccupied with denture \\
\hline Not preoccupied with & problems. Has consulted \\
\hline denture problems & several other dentists \\
\hline $\begin{array}{l}\text { 3. Motivated to succeed with } \\
\text { dentures }\end{array}$ & $\begin{array}{l}\text { Poorly motivated to succeed } \\
\text { with dentures }\end{array}$ \\
\hline $\begin{array}{r}\text { Figure } 4 \text { - prognos } \\
\text { cons }\end{array}$ & $\begin{array}{l}\text { ssed on psychosocial } \\
\text { ations }\end{array}$ \\
\hline
\end{tabular}

\section{Conclusion}

Lack of motivation among the elderly population regarding maintenance of oral health can be attributed to their perceived limited need for oral health care during ageing. This level of perception among the elderly in most of the countries might be because of the low and unevenly distributed dental services during their childhood and adulthood. Hence the primary need would be to educate and motivate the elderly population regarding importance of oral health care.

Treatment of oral disease themselves is equally challenging. Hence to improve the scenario one needs to concentrate on overcoming barriers such as socioeconomic status, general health status, physical and cognitive disabilities and access to dental service among the elderly population. Improper nutrition not only affects physical appearance but also it affects psychological status of patient. Malnutrion is more common in uneducated village people. Prosthodontist is a geriatric dentist who interacts with more number of older people as compare to other profession. So, it is a major role for a prosthodontist to guide the older people regarding malnutrition, balanced diet and age related diseases.

\section{References}

1. Geriatric dentistry - meet the need Rakhi Issrani, Renuka Ammanagi and Vaishali Keluskar The Gerodontology Society and John Wiley \& Sons A/S,Gerodontology2012;29: e1-e5

2. Pereira A, Chiarello G, Luiz O, Faria R.Maintenance of prosthetic treatment in a geriatric patient - Case Report.Braz Dent J1998;9(2): 109-116.

3. Barnes I, Walls A.Gerontology. Wright: Oxford, 1994.

4. Dolan T, Atchinson K.Implications of access, utilization and need for oral health care by the noninstitutionalized and institutionalized elderly on the dental delivery system.J Dent Educ 1993;57:876887.

5. Abrams RA, Ayers CS, Lloyd PM.Attitudes of older versus younger 
adults toward dentistry and dentists.Spec Care Dent1992; 12:67-70.

6. Berkey DB, Berg RG, Ettinger RL, Mersel A, Mann J.The old-old dental patient - the challenge of clinical decision-making.J Am Dent Assoc1996;127:321-332.

7. Patil Manashvini S, Patil Sanjayagouda B.Geriatric patient - psychological and emotional considerations during dental treatment.GerodontologyMarch 2009; 26(6): 72-77.

8. Vincent JR, Tenenbaum MP, Massicotte P. Teaching of geriatric dentistry; training of "mobile dental service" dentists.J Dent1992; 29:15-17.

9. DIET GUIDELINE FOR GERIATRIC PATIENT: A LITERATURE REVIEW Nihar Ranjan Naik ,B.K.Motwani, Shailendra Kumar Sahu International Journal of Dental and Health Sciences Volume 02,Issue 04.
10. Baviskar P, Dodamani A, Wagh S, Baviskar J. Nutrition and Oral Health for Elderly: A Review. International Journal of Scientific Study 2014; 8:177-83.

11. Geriatric Dentistry: Integral Component to Geriatric Patient Care Chih-Ko Yeh Michael S. Kat, Michèle J. Saunders Taiwan Geriatrics \& Gerontology 2008;3(3):182-192)

12. Heartwell C.M. Jr. Syllabus of complete dentures. Fourth edition -1986.

13. Zarb -Bolender: Prosthodontic treatment for edentulous patients, 12 th edition.

14. Sandstead HH. Nutrition in the elderly. Gerodontics 1987;3:3-13

15. Webanalytix.Seniors Should Visit Their GeriatricDentist. Small Business Directory for Dentists (USA), 2008. 